\title{
Comparative Study Between Slide Show Based- Tests and Paper Based-Tests on HIV / AIDS Vocabulary Learning at STIKes ' Aisyiyah Bandung
}

\author{
$1^{\text {st }} \mathrm{P}$ Yualita \\ Sekolah Tinggi Ilmu Kesehatan 'Aisyiyah Bandung \\ Bandung, Indonesia \\ perlayualita3@gmail.com
}

\begin{abstract}
Some institutions conduct various efforts to encounter HIV/ AIDS by increasing the competency of its graduates. They improve their learning achievement tests. One of the tests is a slide show based-test designed in presenting questions suitable for the institutions pioneering into the industrial era 4.0. However, there are still many complaints from students that slide show-based tests are more stressful than paper-based tests. Therefore, the purpose of this study was to determine the comparison of slide show based tests and paper-based tests, especially on HIV / AIDS vocabulary learning at STIKes Aisyiyah Bandung. This study used a quasi-experimental pre-post method with control group design. The percentage of the increased average of slide show-based tests (140.31) is higher than paper-based tests (125.18). Mann Whitney test results showed (0,107> $0,05)$. There is no significant difference between slide show based-tests and paper-based tests. The advantages of slide show-based tests for the institution are increasing time discipline, decreasing student cheating rates, and increasing institutional efficiency in organizing learning outcomes tests.
\end{abstract}

Keywords-Slide show based, tests, HIV, AIDS, Learning

\section{INTRODUCTION}

The information age demands all communities to adapt to the micro and macro environment. If someone cannot adapt to the environment, she/ he will not be able to follow the information development. No exception in the educational world, many innovations are carried out starting from the process of students 'admission (input), the learning process, and output to achieve the quality of education.

Educational innovations develop along with disease treatment innovations, including the treatment of HIV/AIDS in health educational institutions such as nursing school (STIKes). Health students, especially nursing students, have a demand to be able to face the information age and handle the disease treatment. Therefore, they have to know and understand the terminology of diseases and their treatment, including HIV/AIDS terminologies.

One of the efforts of health educational institutions is to balance these two demands by improving the quality of student learning outcomes. A test of learning outcomes can measure the quality of student learning outcomes. Previously, some institutions did manual tests, and now they have turned to innovative tests to be more efficient. One of the innovation tests is a slide show based-test designed through a power point-based program to increase effectiveness and efficiency for both institutions and students.

The result study showed that the score of the acquisition of computer-based exams was $84 \%$, while the acquisition of paper-based exams was $78 \%$ in Computer-Based National Examination [1]. Another result indicated that computer-based tests are one of the solutions for the problems of tests on student admission in college [2].

This study is a continuation of the previous study. The study indicated that the first-year students mastered the HIV / AIDS nursing process jargon (an average of two to a maximum of four jargons) [3]. The subsequent study produced 202 HIV/AIDS jargons/vocabularies. There were several types of vocabularies such as vocabulary definitions, Indonesian vocabularies/ acronyms, English/foreign vocabularies/acronyms [4]. The results of interviews with several respondents obtained a division of HIV / AIDS and non-HIV / AIDS vocabularies. Both institutions and students will get some advantages from this study. They are the improved time discipline and attitudes on both students and supervisors in the implementation of the learning outcome test, the decreased level of students' cheating, and the institution's efficiency in the management of learning test results.

However, based on the results of the preliminary study, the slide show-based tests led to various aspirations of students. They thought that the slide show-based test did not concern with their ability and speed to understand each question, so their stress level was higher. Also, there was a difference between the Indonesian language mid-test scores of the students of the academic year 2018-2019 and the students of the previous year. For this reason, the researcher needs to investigate a difference between slide show based tests and paper-based tests on the student learning outcome, so the leader of STIKes Aisyiyah 
Bandung can decide to determine learning outcome test media.

\section{METHOD}

This study used a quantitative approach. The type of research chosen was a quasi-experiment with a control pretest and post-test. The subjects in this study were all firstyear students in the academic year 2018/2019 at STIKes Aisyiyah Bandung, totaling 54 people divided into 28 people in the experimental class and 26 people in the control class. The sampling technique used was consecutive sampling.

The inclusion criteria selected in this study were firstyear students who were attending an Indonesian language lecture with HIV / AIDS vocabulary material in the even semester of the academic year 2018 / 2019. The exclusion criteria in this study were students who could not be present at the time of the study

The researcher prepared several data collection techniques by doing a documentation study to prepare HIV/AIDS vocabulary materials. Next, the researcher did observations and interviews for the preliminary study and slide show-based tests after that the researcher prepared the slide show-based test and paper-based test tools. Then, the researcher conducted the instrumental validity test on firstyear midwifery diploma 3 and nursing bachelor program students. Besides, the researcher carried out a pre-test to see the level of homogeneity in the experimental class and the control class. After the researcher gave HIV/AIDS vocabulary materials to the students, the researcher provided a slide show -based post-test in the experimental class while the researcher gave a paper-based post-test in the control class. In the last step, the researcher assessed the result of both classes.

The researcher conducted the intervention procedure in the experimental class with the following steps: 1) the researcher gave 30 multiple choice questions using a slide show -based test to the students in the experimental class as a formative for one time because the validity and reliability of the instrument had tested both the multiple-choice and slide show- based test tools. The researcher calculated the level of difficulty by using the easy, medium, difficult ratio with a ratio of 1:2:1 with the proportion of time needed; 2) the researcher conducted the test for 30 minutes with additional time for 15 minutes for rechecking; 3) the researcher collected all students' answers and did a scoring.

This study used a slide show -based and a paper-based multiple-choice test about HIV-AIDS vocabularies as a measuring instrument. The researcher conducted the validity-reliability test on the first-year Midwifery Diploma Program and Nursing Bachelor Program students using anates software.

The researcher conducted data processing techniques with the following steps: 1) by checking, coding, and inputting data to facilitate the processing; 2) by verifying the normality of data using shapiro Wilk in the experimental and the control class because the respondents were less than 50 students; 3 ) by examining the effectiveness of slide show- based test in the experimental class using Wilcoxon; 4) by testing the average difference between the experimental and control classes to see the average of final learning outcomes among both classes using the man Whitney test.

\section{RESULT}

A. Score and Percentage of Increase of Pre-test and Posttest in the Experimental and Control Class

The results of descriptive statistics indicated the percentage of the pre-test and post-test scores in the experimental and control classes, as in table I below.

TABLE 1. PRE-TEST AND POST-TEST IN THE EXPERIMENTAL AND CONTROL CLASS

\begin{tabular}{|c|c|c|c|c|c|c|}
\hline \multirow{2}{*}{ ASPECT } & \multicolumn{3}{|c|}{ Experimentatal Class } & \multicolumn{3}{c|}{ Control class } \\
\cline { 2 - 7 } & Pre-test & Post-test & $\begin{array}{c}\text { Percentage } \\
\text { of increase }\end{array}$ & Pre-test & Post-test & Percentage of increase \\
\hline Highest score & 50.00 & 96.67 & 93.34 & 63.33 & 100 & 57.90 \\
\hline Lowest score & 16.67 & 60.00 & 259,93 & 16.67 & 53.33 & 219.92 \\
\hline Average score & 37.56 & 90.26 & 140.31 & 37.69 & 84.87 & 125.18 \\
\hline
\end{tabular}

An average of the pre-test score using the slide showbased test was 37.56 (E) in the experimental class, while the average of the post-test score was 90.26 (A). The lowest of the pre-test score was only $16.67(\mathrm{E})$, while the lowest of the post-test score reached $60.00(\mathrm{C}+)$. The highest score of the pre-test was only 50.00 (D), while the highest score of the post-test was 96.67 (A). The average of the pre-test score using a paper-based test was 37.69 (E) in the control class, while the average of the post-test score was 84.87 (A). The lowest of the pre-test score was only $16.67(\mathrm{E})$. The lowest of the post-test score was 53.33 (D). The highest score of the pre-test was only $63.33(\mathrm{C}+)$. The highest score of the post-test was 100 (A).

The increasing percentage of the highest score in the experimental class reached $93.34 \%$, while the increasing percentage of the lowest score was $259.93 \%$, and the increasing percentage of the average score reached $140.31 \%$. Furthermore, the increasing percentage of the highest score in the control class reached $57.90 \%$, was the percentage of increase in the lowest score was $219.92 \%$. The increasing percentage of the average score in the control class was $125.18 \%$. Both the experimental class and the control class experienced the increasing percentage, but the increasing percentage in the experimental class was higher than in the control class.

B. Scores and Percentage of Increase in Pre-test and Post-test in the Experimental and Control Class Per Material Aspect 
The results of calculations per aspects of the material obtained the pre-test and post-test scores in the experimental and control classes, as in table II below.

TABLE II. THE INCREASING PERCENTAGE OF AVERAGE PER MATERIAL ASPECTS

\begin{tabular}{|c|c|c|c|c|c|c|}
\hline \multirow{2}{*}{ ASPECT } & \multicolumn{3}{|c|}{ Experimental Class } & \multicolumn{2}{c|}{ Control class } \\
\cline { 2 - 7 } & Pre-test & Post-test & $\begin{array}{c}\text { Percentage } \\
\text { of increase }\end{array}$ & Pre-test & Post-test & $\begin{array}{c}\text { Percentage } \\
\text { of increase }\end{array}$ \\
\hline Definition & $39.68 \%$ & $88.89 \%$ & $49.21 \%$ & $43.16 \%$ & $89.74 \%$ & $46.58 \%$ \\
\hline $\begin{array}{c}\text { English/foreign Vocabularies } \\
\text { / acronyms }\end{array}$ & $38.93 \%$ & $90.36 \%$ & $51.43 \%$ & $38.85 \%$ & $81.15 \%$ & $42.31 \%$ \\
\hline $\begin{array}{c}\text { Bahasa Indonesia } \\
\text { Vocabularies / acronyms }\end{array}$ & $53.57 \%$ & $97.32 \%$ & $43.75 \%$ & $46.15 \%$ & $88.46 \%$ & $42.31 \%$ \\
\hline $\begin{array}{c}\text { Sorting HIV/AIDS and non- } \\
\text { HIV/AIDS vocabularies }\end{array}$ & $22.96 \%$ & $86.73 \%$ & $63.78 \%$ & $24.18 \%$ & $81.87 \%$ & $57.69 \%$ \\
\hline
\end{tabular}

The sorting of HIV/AIDS and non-HIV/AIDS vocabularies $(63.78 \%)$ reached the highest increasing percentage of the pre-test and post-test average scores. The aspect of English/foreign vocabularies/acronyms was on the second rank $(51.43 \%)$. The aspect of vocabulary definition (49.21\%) was on the third rank, while the aspect of Indonesian vocabularies/acronyms was the last rank (43.75\%). Furthermore, the aspect of sorting HIV / AIDS and non-HIV / AIDS vocabularies was on the highest increasing percentage of the pre-test and post-test average scores in the control class $(57.69 \%)$. The aspect of vocabulary definition was on the second $\operatorname{rank}(46.58 \%)$, while the aspect of English / foreign vocabularies/acronyms and Indonesian vocabularies/acronyms was on the last rank (42.31\%).

C. Different Test Results of the Pre-test and Post-Test average score in the Experimental Class

The normality test results of the pre-test in the experimental class using the Shapiro Wilk test obtained $0.172>0.05$, meaning that the data were normally distributed. The normality test results of the post-test in the experimental class showed abnormal data $(0,000<0.05)$. Therefore, the researcher used the Wilcoxon test with a result of $0,000<0.05$, meaning that there was a significant influence before and after doing the slide in the experimental class.

\section{Different Test Results of the Post-Test average score} in the Experimental and the Control Class

The different test results of the post-test average score between the experimental and control class using the Mann Whitney test obtained $0.107>0.05$. Thus, the researcher concluded that there were no significant differences in the score results using slide show-based tests and paper-based tests.

\section{DISCUSSION}

Based on the results of the study above, the average scores of pre-test and post-test in the experimental class using slide show -based tests showed the increasing percentage as many as $140.31 \%$, while the increasing percentage in the control class using paper-based tests was $125.18 \%$. This meant that the increasing percentage in the experimental class using slide show based-test was higher than the increasing percentage in the control class using paper-based tests. Likewise, if the researcher examined the range of increasing percentage of pre-test and post-test, the range of increasing percentage in the experimental class was higher than the control class. The slide show based-test using computer tools essentially provide easiness and train the students to do something honestly [5]. Computer-based tests also provide some experiences and develop the students' performance [6]. Computer Based-Test (CBT) might provide a good test performance and is an efficient tool in the assessment. The result study stated that CBT can also influence students' motivation. That statement indicated there was a strong correlation between the computer-based test and students' motivation [7]. Therefore, it is not surprising that the wilcoxon test results in the experimental class showed significant differences before and after using slide show-based tests (the result of wilcoxon test was $0,000<0.05)$.

However, the different test results of the post-test average in the experimental and the control class using the Mann Whitney test showed no significant difference between the experimental class using the slide show-based test and the control class using the paper-based test (0.107> 0.05). This finding was in line with one research, showing that the results of the CBT test did not correlate significantly with the ability to operate the computer, the attitude, and the test results [8].

Although there were no significant differences between the results of slide show-based tests and paper-based tests, the institutions can continue using the slide show- based tests because the tests do not have a significant impact on the students' grades. Besides, the slide show-based tests are very profitable for the institution to achieve efficiency.

If the researcher analyzed the HIV / AIDS material aspects, the results would show that the students in the experimental and the control class can distinguish the HIV/AIDS vocabularies from non-HIV / AIDS vocabularies. We can see from the highest percentage in the aspect of sorting HIV / AIDS and non-HIV / AIDS vocabularies by $63.78 \%$ in the experimental class and $57.69 \%$ in the control class even though the vocabularies were unfamiliar for them. This was in line with another study, stating that new and unfamiliar vocabularies can be interesting to learn [9]. Other supporting factors can be in the form of vocabulary learning strategies to facilitate the students in remembering the vocabularies. This was along with another study, indicating that mastery of foreign vocabulary is easy to learn when we use certain strategies 
such as flashcards so we can memorize the vocabularies on our memory [10].

The aspects of English vocabularies/acronyms in the experimental class was on the second rank because the students often saw and easily remembered those vocabularies even those are from a foreign language. The another result stated that the students will quickly remember familiar vocabularies [11]. Being different from the experimental class, the aspect of vocabulary definition was on the second rank in the control class $(46.58 \%)$. The students can guess the meaning of words strung together into sentences. This was related to one's opinion stating that vocabulary is not merely memorizing and knowing the meaning, but learning to string words together and defining a word [12].

The aspect of vocabulary definition was on the third rank (49.21\%), and the aspect of Indonesian vocabularies/acronyms was on the fourth rank in the experimental class $(43.75 \%)$. On the contrary, the aspect of English vocabularies/acronyms and the aspect of Indonesian vocabularies/acronyms in the control class had the same percentage $(42.31 \%)$. The Indonesian vocabularies/acronyms placed the last rank because the students seldom use those vocabularies even in their daily life. The result was in line with one's opinion indicating that people will be difficult to remember unfamiliar vocabularies [11].

\section{CONCLUSIONS}

Based on the results and discussion of the study, the researcher drew the following conclusions. The increasing percentage of the slide show-based test score average on HIV / AIDS vocabulary learning (140.31) was higher than the paper-based test (125.18). This indicated that there were significant differences when the researcher only examined the internal of the experimental classroom before and after using slide show based tests. However, the results of the mann whitney test comparing the experimental class and the control class showed that there was no significant difference between the slide show based tests and the paper-based tests. Nevertheless, the learning outcomes tests can use slide show-based test. There are some benefits for institutions to use slide show-based tests, including the increased time discipline, the decreased student cheating rates, and the increased institution's efficiency in managing the learning achievement tests because the slide showbased tests are paperless.

\section{ACKNOWLEDGMENT}

The researcher would like to thank all those who have assisted in the process of completing this study, especially STIKes 'Aisyiyah Bandung. Besides, the researcher does not forget to thank the speakers who were willing to become respondents and all those whom the researcher cannot mention one by one for their support while completing this study. Hopefully, the results of this study can be useful to support the test in education.

\section{REFERENCES}

[1] M. Santi and A. Prajana, "Analisis Implementasi Ujian Nasional Berbasis Komputer Dengan Ujian Berbasis Kertas Di Smpn 3 Ingin Jaya Kabupaten Aceh Besar," Cybersp. J. Pendidik. Teknol. Inf., vol. 2, no. 2, p. 84, 2019, doi: 10.22373/cj.v2i2.3997.

[2] A. Suryadi, "Erancangan Aplikasi Tes Berbasis Komputer (Cbt) Menggunakan Pendekatan Terstruktur Untuk Penerimaan Mahasiswa Baru Di Perguruan Tinggi," J. Petik, vol. 1, no. 1, p. 68, 2018, doi: 10.31980/jpetik.v1i1.59.

[3] P. Yualita, "Pengetahuan Jargon Proses Keperawatan HIV-AIDS Pada Mahasiswa Tk. I Ta. 2013/2014 STIKes 'Aisyiyah Bandung," vol. 1, no. 6, 2014.

[4] P. Yualita, "The Utilization of Jargon in Nursing Learning Process of HIV-AIDS in STIKes "Aisyiyah Bandung," PROCEEDING AIPNEMA, vol. 1, no. 1, pp. 261-269, 2014.

[5] F. Maiziani, "Efektivitas Computer Based Testing Sebagai Sarana Tes Hasil Belajar,” J. Kiprah, vol. 4, no. 1, pp. 15-32, 2016.

[6] B. M. Hakim, "Comparative Study on Validity of Paper-Based Test and Computer-Based Test in the Context of Educational and Psychological Assessment among Arab Students," Int. J. English Linguist., vol. 8, no. 2, p. 85, 2017, doi: 10.5539/ijel.v8n2p85.

[7] Ummah, "Pengaruh Ujian Sistem CBT (Computer Based Test) Mata Pelajaran Pai Terhadap Motivasi Belajar Siswa Sman 10 Surabaya," Society, vol. 2, no. 1, pp. 1-6, 2019, doi: 10.1017/CBO9781107415324.004.

[8] H. Khoshsima, S. M. H. Toroujeni, N. Thompson, and M. R. Ebrahimi, "Computer-based (CBT) vs. paper-based (PBT) testing: Mode effect, relationship between computer familiarity, attitudes, aversion and mode preference with CBT test scores in an asian private EFL context," Teach. English with Technol., vol. 19 , no. 1 , pp. 86-101, 2019.

[9] R. H. Albakri, “AWEJ Arab World English Journal," AWEJ, vol. Volume 4, no. 2, pp. 269-284, 2013, [Online]. Available: www.awej.org.

[10] S. Kashani and S. Shafiee, "A Comparison of Vocabulary Learning Strategies among Elementary Iranian EFL Learners," $J$. Lang. Teach. Res., vol. 7, no. 3, p. 511, 2016, doi: 10.17507/j1tr.0703.11.

[11] Salamadian, "700 Kosakata Bahasa Inggris bagi Pemula (Recommended) yang sering digunakan sehari-hari," Online, 2016. .

[12] H. Basri, M. R. Ridla, and A. Wahed, "Strategi Belajar Kosakata Bahasa Inggris (English Vocabulary) Mahasiswa TBI STAIN Pamekasan," OKARA J. Bhs. dan Sastra, vol. 8, no. 2, pp. 153166,2014 